\title{
UPAYA PENINGKATAN KREATIF-PRODUKTIF MAHASISWA BERBASIS INFORMASI WEB PADA MATA KULIAH RISET OPERASI
}

\author{
${ }^{1}$ Edy Suprapto, ${ }^{2}$ Reza Kusuma Setyansah \\ ${ }^{1}$ Dosen Prodi Matematika IKIP PGRI Madiun \\ ${ }^{2}$ Dosen Prodi Matematika IKIP PGRI Madiun \\ ${ }^{1}$ Email: edypraja@gmail.com \\ ${ }^{2}$ Email: rezasetyansah@gmail.com
}

\begin{abstract}
Abstrak. Penelitian ini bertujuan untuk melatihkan tingkat kreativitas dan produktivitas mahasiswa yang selanjutnya diharapkan akan membantu meningkatkan prestasi belajar mahasiswa. Penelitian ini merupakan Penelitian Tindakan Kelas (PTK) yang terdiri dari tiga siklus. Pada masing-masing siklus memiliki empat tahap yaitu, tahap perencanaan, tahap pelaksanaan, tahap pengamatan dan tahap refleksi. Subjek penelitian ini adalah mahasiswa semester genap (kelas VI-A) tahun akademik 2011/2012 yang berjumlah 37 orang. Adapun teknik pengumpulan data dilakukan dengan wawancara, observasi langsung dan tes. Analisa data yang dilakukan adalah analisis diskriptif kualitatif.

Dari hasil penelitian 37 orang mahasiswa pada siklus I diperoleh banyaknya mahasiswa yang tuntas adalah $13,51 \%$ dan $86,49 \%$ mahasiswa yang tidak tuntas.Pada siklus II diperoleh banyaknya mahasiswa yang tuntas adalah $27,03 \%$ dan $72,97 \%$ mahasiswa yang tidak tuntas. Pada siklus III diperoleh banyaknya mahasiswa yang tuntas adalah72,97\% dan 27,03\% mahasiswa yang tidak tuntas. Hal ini menunjukkan adanya peningkatan yang cukup berarti. Pada perlakuan Siklus II dan siklus III selain terdapat peningkatan prestasi, penerapan media websitemampu meningkatkan kreativitas dan produktivitas mahasiswa dalam perkuliahan riset operasi pada materi program linier.
\end{abstract}

Keywords: Riset Operasi, Kreativitas, Produktivitas, Website.

\section{PENDAHULUAN}

Perkembangan ilmu pengetahuan dan teknologi dewasa ini semakin pesat sehingga mengakibatkan banyaknya perubahan di berbagai bidang, salah satu diantaranya yaitu pada bidang pendidikan. Pendidikan merupakan salah satu hal penting bagi manusia, karena menyangkut kelangsungan hidup manusia dan tingkat kecerdasan bangsa. Oleh karena itu keberadaan teknologi tentu saja sangat diharapkan akan dapat membantu dalam peningkatan kualitas pendidikan itu sendiri.

Upaya peningkatan kualitas pendidikan merupakan pengemban utama di dalam peningkatan kualitas sumberdaya manusia untuk menjadi pribadi yang kreatif dan mandiri. Terciptanya sumber daya manusia yang berkualitas ini diawali dari hadirnya lulusan yang bermutu. Di dalam mewujudkan mutu lulusan dari setiap institusi atau lembaga pendidikan, dapat diupayakan melalui proses pembelajaran yang dilaksanakan. Pelaksanaan pembelajaran tidak terlepas dari komponen-komponen yang harus dikembangkan pengajar, meliputi tujuan, materi, strategi pembelajaran termasuk didalamnya model, metode dan media pembelajaran serta evaluasi hasil belajar.

Selain daripada itu, hasil belajar yang harus dicapai bukan hanya sekedar tahu, menguasai ilmu dan menghafal semua teori yang dihasilkan orang lain, tetapi belajar merupakan proses berpikir. Namun dalam realita proses pembelajaran, seorang dosen masih menggunakan metode yang monoton dan kurang sesuai dengan materi yang diajarkan dan karakteristik mahasiswa. Pembelajaran yang demikian akan sangat membosankan bagi mahasiswa sehingga motivasi belajar mereka akan menjadi semakin rendah. Akibat yang lebih jauh adalah mahasiswa akan malas 
untuk belajar dan kemampuan mereka tidak akan tergali secara maksimal.

Salah satu ilmu yang saat ini senantiasa selalu dikembangkan adalah matematika. Namun, perkembangan pembelajaran matematika di lembaga pendidikan, ternyata belum sesuai dengan apa yang diharapkan. Di mana, selain prestasi mahasiswa yang masih rendah, tingkat kreatif dan produktif mahasiswa juga tergolong masih rendah. Hal ini terlihat dari sebagian mahasiswa masih belum mampu mengaplikasikan ilmu pengetahuan yang diperoleh pada kehidupan nyata.

Berdasarkan realita yang ada, ternyata memang tidak semua mahasiswa mampu menggali kreatif dan produktifnya dengan baik, artinya sampai saat ini kemampuan mahasiswa dalam hal tersebut masih menjadi masalah bagi sebagian mereka. Sebagian mahasiswa masih kesulitan dalam mengaplikasikan teori dalam matematika pada permasalahan nyata. Hal tersebut juga didukung dengan sangat minimnya kreativitas mahasiswa dalam menyelesaikan permasalahanpermasalahan yang terkait dengan matematika. Akibatnya, tentu saja akan berdampak pada rendahnya prestasi belajar mereka.

Salah satu cabang interdisiplin dari matematika yang dapat dijadikan sebagai salah satu alternatif melatihkan kreativitas dan produktivitas bagi mahasiswa adalah riset operasi, satu diantaranya yaitu pada materi program linear. Pada materi tersebut, mahasiswa dapat dilatih untuk lebih kreatif dan produktif dalam mengaplikasikan ilmu yang diperoleh pada keadaan nyata.

Berkaitan dengan upaya melatihkan kreatif dan produktif mahasiswa, tentu saja dosen sebaiknya juga mampu memilih model pembelajaran yang tepat, artinya efektif dan menarik. Menurut Widiyanto (2008: 2), Model pembelajaran matematika yang efektif dan menarik adalah model pembelajaran yang memiliki nilai relevansi dengan pencapaian daya matematika, memberi peluang untuk bangkitnya kreativitas, mampu mengembangkan suasana belajar mandiri dan sejauh mungkin memanfaatkan momentum kemajuan teknologi khususnya fungsi teknologi informasi. Mengacu pada pendapat tersebut, maka dalam penelitian ini akan digunakan model pembelajaran yang lebih menitikberatkan pada keterlibatkan mahasiswa dalam kegiatan pembelajarannya, serta memanfaatkan media website. Media website akan digunakan sebagai sarana untuk menuangkan hasil akhir kerja mahasiswa selama proses pembelajaran, dengan harapan mahasiswa yang lain dapat saling berbagi informasi utamanya pada mata kuliah riset operasi.

Adapun tujuan dalam penelitian ini untuk mengetahui: 1) Untuk mengetahui apakah model pembelajaran yang diterapkan dosen berpengaruh terhadap tingkat kreativitas dan produktivitas mahasiswa. 2) Untuk mengetahui apakah model pembelajaran yang berorientasi pada pengembangan kreativitas dan produktivitas mahasiswa mampu membantu meningkatkan prestasi belajar mahasiswa.

\section{METODE PENELITIAN}

Jenis penelitian ini adalah penelitian tindakan kelas(PTK) yang bersifat reflektif, partisipatif, kolaboratif dan spiral, bertujuan untuk melakukan perbaikan-perbaikan terhadap sistem, cara kerja, proses, isi, dan kompetensi atau situasi pembelajaran. Menurut Suharsimi Arikunto (2006:3) Penelitian Tindakan Kelas adalah merupakan suatu pencermatan terhadap kegiatan belajar berupa sebuah tindakan, yang sengaja dimunculkan dan terjadi dalam sebuah kelas secara bersama yang diberikan dan diarahkan oleh guru atau calon guru yang dilakukan oleh siswa. Sementara itu, Herawati Susilo (2008: 1) menyatakan bahwa PTK adalah sebuah proses investigasi terkendali yang berdaur ulang dan bersifat reflektif mandiri yang dilakukan oleh guru atau calon guru yang memiliki tujuan untuk melakukan perbaikan-perbaikan 
terhadap sistem, cara kerja, proses, isi, kompetensi atau situasi pembelajaran. Hal senada juga diungkapkan oleh McNiff (dalam Suroso, 2007:19), bahwa Penelitian Tindakan Kelas merupakan bentuk penelitian reflektif yang dilakukan oleh peneliti yang hasilnya dapat dimanfaatkan sebagai alat pengembangan kurikulum, pengembangan sekolah, pengembangan keahlian mengajar dan sebagainya.

Dari beberapa definisi di atas dapat disimpulkan bahwa Penelitian Tindakan Kelas adalah proses investigasi yang berdaur ulang dan bersifat reflektif yang dilakukan oleh guru atau calon guru yang menyangkut masalah-masalah kelas dan masalah-masalah pembelajaran.

Rencana pelaksanaan penelitian dilakukan dalam 3 siklus. Tiap siklus dilakukan dalam 2 kali pertemuan. Menurut Suharsimi Arikunto (2006:16) secara garis besar dalam tiap siklus terdiri dari 4 tahapan, yaitu: (1) perencanaan (planning), (2) pelaksanaan (acting), (3) pengamatan (observing) dan (4) refleksi (reflecting).

Adapun model penjelasan untuk masingmasing tahap adalah sebagai berikut:

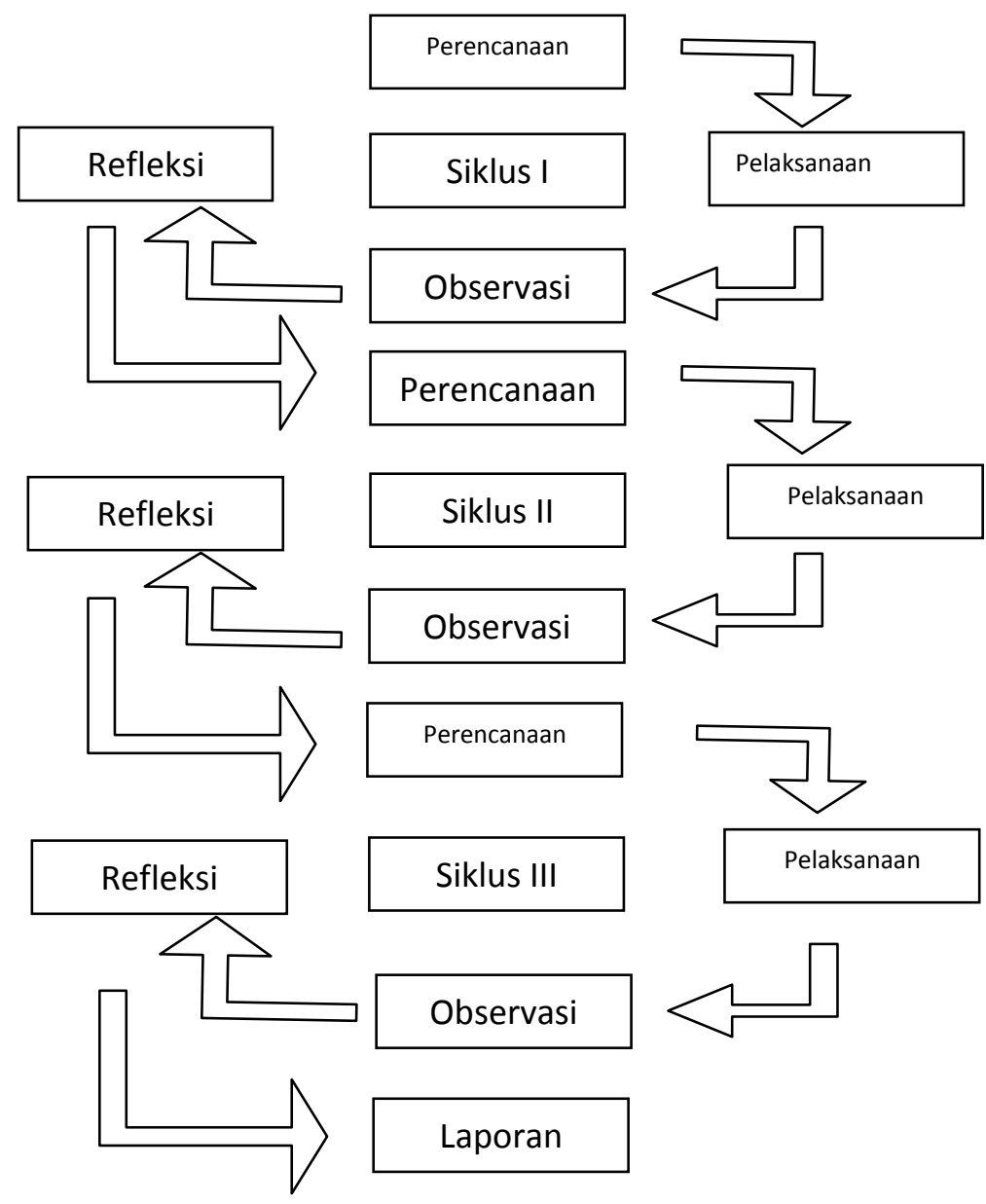

Gambar 1. Alur Metode Penelitian

Adapun tahap pelaksanaan kegiatan pembelajaran tiap siklusnya adalah sebagai berikut. 1) Tahap Perencanaan Tindakan Sebelum melaksanakan tindakan maka perlu tindakan persiapan.
Kegiatan pada tahap ini diantaranya : a ) Penyusunan Silabus dan RPP dengan model pembelajaran yang direncanakan dalam PTK. b) Penyusunan Lembar Kerja Mahasiswa (LKM) sesuai dengan 
indikator pembelajaran yang ingin dicapai. c) Menyusun instrumen tes yang akan digunakan untuk mengevaluasi hasil belajar siswa. 2) Tahap Pelaksanaan Tindakan, dalam tahapan ini, penelitian tindakan adalah melaksanakan kegiatan sesuai dengan rencana pembelajaran yang telah dibuat. Dalam pelaksanaan penelitian,dosen menjadi fasilitator selama kegiatan pembelajaran. Selanjutnya di akhir pelaksanaan pembelajaran pada tiap siklus, dosen memberikan test secara tertulis untuk mengevaluasi hasil belajar mahasiswa selama proses pembelajaran berlangsung. 3) Tahap Pengamatan atau Observasi Pada saat proses pembelajaran berlangsung dilakukan observasi yang digunakan untuk memperoleh bahan penyusunan refleksi. Pada tahap ini dosen berkolaborasi dengan peneliti yang lainnya selama proses pembelajaran berlangsung. Kegiatan ini dimaksudkan untuk mengamati langkah-langkah yang dilakukan peneliti dalam mengajar sehingga akan tampak kekurangankekuranganya dan dapat dijadikan bahan acuan dalam menyusun perencanaan tindakan dalam siklus II. 4) Tahap Refleksi. Kegiatan refleksi merupakan kegiatan untuk mengemukakan kembali dari tahap pelaksanaan. Kegiatan ini dilakukan ketika peneliti sudah selesai melakukan tindakan. Kegiatan ini diawali dengan memeriksa catatan hasil observasi. Semua hasil observasi digunakan sebagai acuan untuk melakukan perbaikan pada siklus berikutnya. Hal tersebut dilakukan apabila masih terdapat kekurangan pada siklus sebelumnya. Dengan refleksi ini akan didapat suatu masukan atau bahan pertimbangan yang sangat berharga dan akurat bagi penentuan langkah tindakan pada siklus II. Kegiatan pada siklus II pada dasarnya sama dengan pada siklus I, hanya saja pada perencanaan kegiatannyadidasarkan pada hasil refleksi pada siklus I sehingga lebih mengarah pada perbaikan pelaksanaan siklus I. Setelah menyusun rancangan untuk siklus II, peneliti melanjutkan ke tahap pelaksanaan, pengamatan dan refleksi, yang cara dan masing-masing tahapannya sama dengan siklus I. Pada Siklus III, Setelah mengetahui letak keberhasilan dan hambatan dari siklus I dan siklus II, peneliti menentukan rancangan atau perencanaan untuk siklus III. Setelah menyusun perencanaan siklus III, peneliti melanjutkan ke tahap pelaksanaan, pengamatan dan refleksi, yang cara dan masing-masing tahapannya sama seperti siklus I dan siklus II.

Analisis data dilakukan untuk mengetahui bagaimana cara mengolah data yang diperoleh serta menentukan rumus statistik yang berhubungan dengan penelitian ini. Data yang dianalisis adalah data hasil tes belajar siswa pada setiap akhir siklus. Penilaian tes dilakukan untuk menilai perorangan (individu). Berdasarkan Standart Ketuntasan Belajar Minimal (SKBM) di IKIP PGRI Madiun, mahasiswa dikatakan tuntas dalam belajar apabila siswa tersebut memperoleh nilai $\geq 65$. Untuk mencari ketuntasan belajar siswa digunakan rumus sebagai berikut:

Prosentase Tuntas $=\frac{\text { Jumlah Siswa yang Tuntas }}{\text { Jumlah Seluruh Siswa }} \times 100 \%$

Prosentase ketuntasan belajar dikatakan berhasil jika memenuhi ketuntasan belajar $\geq 65$. Sedangkan prosentase ketuntasan belajar tidak berhasil jika ketuntasan belajar siswa $<65$.

\section{HASIL DAN PEMBAHASAN}

hasil penelitian di kelas VI-A Program Studi Pendidikan Matematika FPMIPA IKIP PGRI Madiun yang berkaitan dengan permasalahan yang ada pada rumusan masalah. Untuk menjawab permasalahan tersebut, peneliti menganalisis hasil data perolehan penelitian. Adapun hasil observasi dan hasil tes pada setiap siklus yang diperoleh sebagai berikut: Pada kegiatan siklus I materi yang diajarkan adalah konsep awal dari program linear dan aplikasinya. Adapun hasil kegiatan penelitiannya dapat dikemukakan sebagai berikut: tahap pertama Dalam 
tahap ini dosen/peneliti menyiapkan perangkat pembelajaran yang terdiri dari silabus dan RPP.

Setelah perencanaan, dosen/peneliti melaksanakan tindakan belajar mengajar pada siklus I. Pelaksanaan kegiatan pembelajaran diawali dengan memotivasi mahasiswa dan dosen menyampaikan tujuan pembelajaran. Kemudian dosen membentuk mahasiswa menjadi 9 kelompok, setiap kelompok terdiri dari 4-5 mahasiswa. Dalam proses belajar, dosen memberi materi yang sudah dipersiapkan kepada mahasiswa. Kemudian dosen memberikan soal kepada mahasiswa untuk dikerjakan bersama. Setelah mahasiswa selesai mengerjakan, dosen membahas bersama dengan mahasiswa soal yang telah diberikan. Selanjutnya dosen memberikan waktu pada mahasiswa untuk membenarkan jawaban yang salah. Setelah mahasiswa selesai dosen memberikan tes essay secara individu.

Berdasarkan hasil pembelajaran siklus I diperoleh rangkuman prosentase hasil evaluasi (tes) sebagai berikut:

Tabel 1. Prosentase Hasil Evaluasi Pada Siklus I

\begin{tabular}{cccc}
\hline No & $\begin{array}{c}\text { Interval } \\
\text { Nilai }\end{array}$ & $\begin{array}{c}\text { Jumlah } \\
\text { Mahasiswa }\end{array}$ & Prosentase (\%) \\
\hline 1 & $65-100$ & 5 & 13,51 \\
2 & $0-64$ & 32 & 86,49 \\
\hline \multicolumn{2}{c}{ Total } & $\mathbf{3 7}$ & $\mathbf{1 0 0}$
\end{tabular}

Dari data di atas terlihat bahwa masih terdapat sekitar $86,49 \%$ mahasiswa yang belum tuntas, artinya nilai tes mereka masih berada dibawah nilai Standart Ketuntasan Belajar Minimal (SKBM) yaitu kurang dari 65. Di sisi lain dapat dilihat bahwa mahasiswa yang tuntas hanya sekitar 13,51\%. Hal ini mengindikasikan bahwa proses pembelajaran pada siklus I bisa dikatakan masih belum berhasil (belum sesuai dengan harapan).

Pada tahap ini dosen mengevaluasi hasil observasi dari perolehan hasil. Pada saat pembelajaran berlangsung, beberapa permasalahan yang muncul antara lain: 1) Dalam pelaksanaan pembelajaran dosen belum menyampaikan garis besar dan proses pelaksanaan pembelajaran sehingga mahasiswa mengalami kesulitan dalam memahami materi pelajaran. 2) Pada saat diskusi masih banyak mahasiswa yang pasif dan cenderung tidak memperhatikan materi yang disampaikan dosen. 3) Mahasiswa belum banyak terlibat secara langsung dalam kegiatan pembelajaran dan belum mempunyai gambaran secara jelas aplikasi dari materi pada kehidupan nyata.

Berdasarkan hasil keseluruhan dari siklus I, secara umum dapat disimpulkan bahwa indikator pembelajaran masih belum dapat tercapai dan akan diperbaiki pada siklus selanjutnya. Selanjutnya beberapa perbaikan yang direncanakan pada siklus berikutnya berkaitan dengan permasalahanpermasalahan pada siklus I diantaranya: 1) Dosen mengupayakan penjelasan yang lebih terperinci mengenai materi yang diajarkan agar mahasiswa tidak kesulitan memahami pelajaran. 2) Dosen harus lebih disiplin dan tegas agar mahasiswa memperhatikan pelajaran. 3) Dosen dapat memberikan tugas yang lebih melibatkan mahasiswa secara langsung untuk mengaplikasikan materi, sehingga diharapkan mahasiswa akan lebih mudah memahami materi secara menyeluruh dan mengetahui aplikasi materi pada kehidupan nyata.

Pada kegiatan siklus II, peneliti masih memperdalam pemahaman materi program linear pada mahasiswa. Beberapa kegiatan pada siklus II dikembangkan dengan mengacu beberapa permasalahan pada siklus I. Adapun hasil kegiatan penelitiannya dapat dikemukakan sebagai berikut:

Dalam tahap ini peneliti menyiapkan perangkat pembelajaran yang terdiri dari: 1) Rencana Pelaksanaan Pembelajaran atau RPP. 2) Tugas yang melatihkan mahasiswa untuk menuliskan hasil perhitungan berdasarkan sistem perhitungan metode progam linier yang diterapkan pada permasalahan nyata, yaitu yang dihadapi oleh masyarakat di lapangan, utamanya 
pada industri rumahan (home industry). Tugas yang diberikan pada mahasiswa selanjutnya dituangkan dalam bentuk karya tulis mahasiswa. Adapun tujuan pengadaan karya tulis sebagai tugas mahasiswa diantaranya diharapkan dapat melatih kreativitas mahasiswa dalam menyajikan karyanya, mampu membantu pemahaman mahasiswa pada materi program linear, dan diharapkan pula akan berdampak pada peningkatan prestasi belajar mahasiswa.

Pelaksanaan pembelajaran pada siklus ini diawali dengan mengulang sekilas materi yang telah dijelaskan pada pertemuan sebelumnya. Sebelumnya dosen juga sudah memastikan mahasiswa berada pada kelompoknya masing-masing. Selanjutnya dosen memberikan tugas dan juga memberikan arahan kepada mahasiswa tentang bagaimana tugas tersebut dikerjakan. Dalam pembelajaran ini, dosen lebih berperan sebagai motivator dan konselor, karena diharapkan mahasiswa bisa lebih aktif dan kreatif dalam menyelesaikan tugas. Pada tahap ini dosen memberikan tugas kepada mahasiswa untuk terjun secara langsung di lapangan (masyarakat) mencari contoh kasus yang dapat diselesaikan dengan metode-metode dalam materi program linear, dan dosen bertugas memberi bimbingan selama mahasiswa menyelesaikan tugas tersebut. Selanjutnya, pada pertemuan berikutnya dosen memberikan tes untuk mengukur sejauh mana pemahaman mahasiswa terhadap materi program linear. Berdasarkan hasil pengamatan dari siklus II, yaitu mengenai aktifitas mahasiswa dan hasil nilai tes yang diperoleh, ternyata belum menunjukkan peningkatan proses pembelajaran yang berarti. Hal itu terlihat dari kurangnya kreativitas mahasiswa dalam menulis karyanya, serta hasil evaluasi (tes) yang belum mengalami perkembangan secara signifikan. Meskipun begitu, kegiatan pembelajaran yang sudah dilaksanakan memberikan pengaruh yang lebih baik terhadap antusiasme mahasiswa dalam mengikuti kegiatan pembelajaran.
Adapun hasil observasinya dapat dijelaskan sebagai berikut:1) Dari hasil karya tulis yang dibuat mahasiswa masih belum disajikan secara baik, diantaranya tata tulis yang belum tertata rapi, penerapan materi program linear terhadap sistem aplikasi kondisi nyata belum dikuasai penuh oleh mahasiswa.

2) Dari hasil evaluasi (tes) diperoleh rangkuman hasil sebagai berikut:

Tabel 2. Prosentase Hasil Evaluasi Pada Siklus II

\begin{tabular}{cccc}
\hline No. & $\begin{array}{c}\text { Interval } \\
\text { Nilai }\end{array}$ & $\begin{array}{c}\text { Jumlah } \\
\text { Mahasiswa }\end{array}$ & Prosentase (\%) \\
\hline 1 & $65-100$ & 10 & 27,03 \\
2 & $0-64$ & 27 & 72,97 \\
\hline & Total & $\mathbf{3 7}$ & $\mathbf{1 0 0}$ \\
\hline
\end{tabular}

Dari data di atas terlihat bahwa terdapat sekitar $72,97 \%$ mahasiswa yang belum tuntas, artinya nilai tes mereka masih berada dibawah nilai Standart Ketuntasan Belajar Minimal (SKBM) yaitu kurang dari 65. Sementara itu banyaknya mahasiswa yang tuntas sejumlah $27,03 \%$. Hasil tes pada siklus II sudah sedikit mengalami peningkatan apabila dibandingkan hasil tes pada siklus I, meskipun secara umum masih dikatakan belum sesuai dengan apa yang diharapkan.

Pada tahap ini dosen mengevaluasi hasil observasi dari perolehan hasil tes. Selama proses pembelajaran muncul beberapa dugaan terkait dengan masih banyaknya mahasiswa dengan nilai di bawah Standart Ketuntasan Belajar Minimal (SKBM), diantaranya: 1) Mahasiswa masih kesulitan dalam sistematika penyelesaian masalah nyata ke dalam bentuk program linear. 2) Mahasiswa hanya terfokus pada tugas kelompok mereka sendiri, sedangkan tugas kelompok yang lain mereka tidak mengetahuinya. Hal ini tentu saja menyebabkan informasi berbagai macam permasalahan yang sebenarnya bisa diselesaikan dengan program linear menjadi kurang.

Berdasarkan hasil keseluruhan dari siklus II, secara umum dapat disimpulkan bahwa indikator pembelajaran juga masih belum dapat 
tercapai dan akan diperbaiki pada siklus selanjutnya. Selanjutnya beberapa perbaikan yang direncanakan pada siklus selanjutnya berkaitan dengan permasalahan-permasalahan pada siklus I diantaranya: 1)Dosen lebih mengintensifkan bimbingan selama mahasiswa menyelesaikan tugasnya. 2) Dosen mengupayakan untuk membimbing mahasiswa untuk bisa saling berbagi informasi hasil karya tulisnya, yaitu dengan cara memanfaatkan kemajuan teknologi informasi melalui internet. Dalam hal ini, mahasiswa diminta untuk dapat membuat suatu website pribadi yang berupa blog pribadi pada setiap kelompok yang telah ditentukan. Selanjutnya mahasiswa diminta untuk mengunggah hasil karya tulis mereka pada blog masing-masing dengan tujuan saling bertukar informasi dengan mahasiswa yang lainnya. Kegiatan ini juga diharapkan dapat melatihkan mahasiswa untuk belajar secara mandiri dan produktif dengan menciptakan sebuah media yang dapat dinikmati oleh orang lain, yaitu berupa website.

Pada kegiatan siklus III, peneliti lebih memperdalam pemahaman mahasiswa tentang materi program linear dan aplikasinya pada permasalahan nyata. Beberapa kegiatan pada siklus III dikembangkan dengan mengacu beberapa permasalahan pada siklus I dan siklus II. Adapun hasil kegiatan penelitiannya dapat dikemukakan sebagai berikut: 1) Tahap perencanaan, dosen memberikan kesempatan untuk menyampaikan kendala-kendala yang dihadapi mahasiswa selama kegiatan penyelesaian tugas. Selain itu dosen juga memberikan tugas tambahan untuk melatihkan produktivitas mahasiswa dengan meminta masing-masing kelompok mahasiswa membuat website pribadi yang berupa blog pribadi yang selanjutnya digunakan untuk mengunggah hasil karya tulis mereka, sehingga dapat saling berbagi informasi dengan kelompok mahasiswa yang lainnya, khususnya mengenai contohcontoh aplikasi program linear dan penyelesaiannya pada permasalahan nyata. 2) Tahap Tindakan, Pelaksanaan pembelajaran pada siklus ini berisi presentasi dan diskusi mengenai gambaran hasil penyelesaian tugas di lapangan serta kendala-kendala yang dihadapi masing-masing kelompok mahasiswa dalam menyelesaikan tugasnya dan dalam menyusun karya tulis mereka. Dalam hal ini dosen lebih berperan sebagai konselor. Kegiatan bimbingan ini juga dilakukan di luar jam perkuliahan apabila kelompok mahasiswa mengalami kendala dalam penyelesaian tugasnya. Selain itu, dosen menjelaskan tentang bagaimana cara membuat produk yang berupa website pribadi dan cara mengunggah hasil karya masing-masing kelompok pada website yang sudah mereka buat. Beberapa contoh alamat website.

Selanjutnya pada pertemuan berikutnya, dosen memberikan tes guna mengukur sejauh mana pemahaman mahasiswa terhadap materi program linear. Hal tersebut juga untuk mengetahui sejauh mana tingkat keberhasilan beberapa upaya yang telah dilakukan oleh dosen mulai dari siklus I, siklus II dan siklus III. 3) Tahap Observasi, Berdasarkan hasil observasi dari siklus III dapat dijelaskan hasilnya sebagai berikut: 1) Tingkat kreativitas penyusunan karya tulis pada siklus III lebih baik apabila dibandingkan hasil pada siklus II. Hal itu dapat dilihat dari tata tulis yang lebih rapi dan cara penyelesaian permasalahan yang lebih sistematis. 2) Dari hasil evaluasi (tes) pada siklus III diperoleh rangkuman hasil sebagai berikut:

Tabel 3. Prosentase Hasil Evaluasi Pada Siklus III

\begin{tabular}{cccc}
\hline No. & $\begin{array}{c}\text { Interval } \\
\text { Nilai }\end{array}$ & $\begin{array}{c}\text { Jumlah } \\
\text { Mahasiswa }\end{array}$ & $\begin{array}{c}\text { Prosentase } \\
(\boldsymbol{\%})\end{array}$ \\
\hline 1 & $65-100$ & 27 & 72,97 \\
2 & $0-64$ & 10 & 27,03 \\
\hline \multicolumn{2}{l}{ Total } & $\mathbf{3 7}$ & $\mathbf{1 0 0}$ \\
\hline
\end{tabular}

Dari data di atas terlihat bahwa terdapat sekitar $72,97 \%$ mahasiswa yang tuntas, hal ini menunjukkan perkembangan peningkatan hasil tes yang signifikan apabila dibandingkan hasil tes pada 
siklus I dan siklus II, khususnya pada materi program linear. Meskipun begitu masih terdapat sekitar 27,03\% mahasiswa yang mendapatkan nilai di bawah Standart Ketuntasan Belajar Minimal (SKBM). 3) Dari hasil produktivitas mahasiswa, mereka sudah mampu berlatih menciptakan sebuah website yang diharapkan dapat digunakan untuk saling berbagi informasi untuk orang lain, khususnya mengenai informasi program linear dan aplikasinya.

Berdasarkan perkembangan prestasi mahasiswa, khususnya hasil nilai tes pada siklus I, II dan III, maka dapat dikatakan bahwa pembelajaran yang sudah diterapkan oleh dosen memiliki pengaruh yang sangat baik terhadap pemahaman mahasiswa pada materi program linear. Selain itu, kegiatan pembelajaran yang dilakukan oleh dosen telah mampu melatihkan mahasiswa untuk menjadi lebih kreatif dan produktif, yang tentunya hal itu diharapkan akan dapat mereka terapkan pada permasalahan-permasalahan yang lainnya.

Berdasarkan hasil penelitian dari beberapa siklus yang telah dilaksanakan oleh peneliti, dapat dirangkum rekapitulasi ketuntasan hasil belajar mahasiswa sebagai berikut:

Tabel 4. Rekapitulasi Hasil Evaluasi pada Masing-

\begin{tabular}{cccc}
\multicolumn{4}{c}{ masing Siklus } \\
\hline Siklus & Tuntas & Tidak Tuntas & Siklus \\
\hline I & $13,51 \%$ & $86,49 \%$ & I \\
II & $27,03 \%$ & $72,97 \%$ & II \\
III & $72,97 \%$ & $27,03 \%$ & III \\
\hline
\end{tabular}

Secara grafik, hasil rekapitulasi di atas dapat disajikan sebagai berikut:

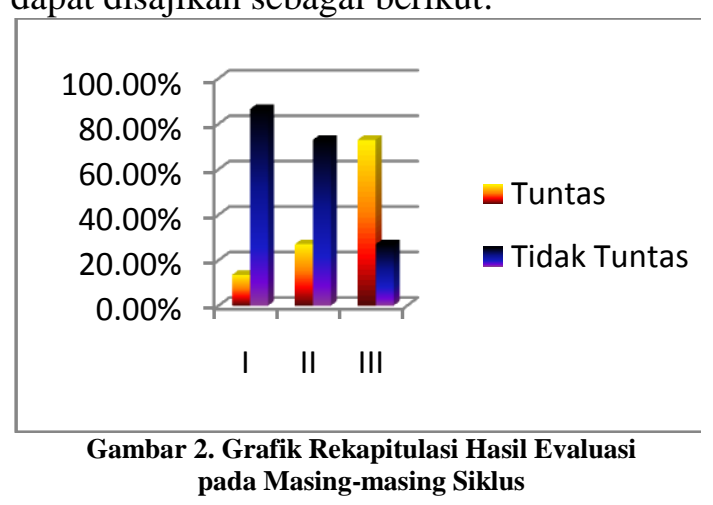

Dari hasil rekapitulasi prosentase ketuntasan belajar mahasiswa pada materi program linear di atas, dapat diketahui bahwa terjadi peningkatan ketuntasan mahasiswa dalam hasil evaluasi belajarnya. Hal ini mengindikasikan bahwa pada setiap siklus, mahasiswa mengalami peningkatan pemahaman terhadap materi, sehingga mereka dapat menyelesaikan soal tes yang diberikan oleh dosen dengan baik.

Terlepas dari hal tersebut, tentu saja beberapa upaya yang telah dilakukan oleh dosen juga memberikan pengaruh yang baik terhadap pemahaman materi oleh mahasiswa pada setiap siklus apabila dibandingkan dengan siklus sebelumnya. Upaya-upaya tersebut diantaranya: pembelajaran dengan model berkelompok, pemberian tugas secara terbimbing untuk langsung mengaplikasikan teori pada keadaan nyata dan pemanfaatan kemajuan teknologi informasi (internet) sebagai upaya untuk saling bertukar informasi. Melalui upaya-upaya tersebut, secara tidak langsung juga telah menjadikan kegiatan pembelajaran lebih menyenangkan dan yang tidak kalah pentingnya yaitu mampu melatihkan kepada mahasiswa untuk menjadi pribadi yang kreatif dan produktif.

\section{SIMPULAN DAN SARAN}

Kesimpulan

Berdasarkan hasil penelitian yang telah dikemukakan di bab IV serta mengacu pada perumusan masalah di depan, maka dapat disimpulkan bahwa: 1) Pemilihan model pembelajaran yang tepat ternyata mampu meningkatkan tingkat kreativitas dan produktivitas mahasiswa. Hal tersebut dapat dilihat dari kegiatan pembelajaran yang dilakukan peneliti pada setiap siklusnya ternyata mampu meningkatkan antusiasme belajar mahasiswa, yang secara tidak langsung juga melatihkan mahasiswa untuk lebih kreatif dalam menyusun karyanya serta mampu produktif untuk menciptakan 
suatu media guna mempublikasikan hasil karyanya, salah satu contohnya yaitu dengan pemanfaatan media website. 2) Model pembelajaran yang berorientasi pada pengembangan kreativitas dan produktivitas, ternyata mampu meningkatkan prestasi belajar mahasiswa. Hal itu terlihat dari peningkatan ketuntasan belajar mahasiswa pada setiap siklusnya.

Saran

Berdasarkan kesimpulan di atas dapat disampaikan beberapa saran berikut : 1) Dosen, a) Dosen hendaknya mampu memilih model pembelajaran yang lebih berorientasi pada keterlibatan langsung mahasiswa dalam kegiatan pembelajarannya. Adapun salah satu contohnya yaitu kegiatan yang berorientasi pada peningkatan tingkat kreativitas dan produktivitas mahasiswa, misalnya dengan menugaskan mahasiswa secara langsung di lapangan untuk mengaplikasikan teori-teori yang diajarkan. b) Dosen hendaknya juga dapat memanfaatkan kemajuan di bidang teknologi untuk melatihkan tingkat kreativitas dan produktivitas mahasiswa, misalnya pemanfaatan media informasi website secara optimal supaya dapat berdaya guna dan berhasil guna. 2) Mahasiswa, a) Mahasiswa diharapkan senantiasa lebih giat dalam belajar dan serius dalam mengikuti perkuliahan agar lebih mudah dalam memahami materi yang disampaikan oleh dosen. b) Mahasiswa hendaknya belajar untuk lebih mandiri dan mampu memanfaatkan kemajuan teknologi untuk menciptakan kreativitas maupun produktivitas yang dapat berguna bagi diri sendiri maupun bagi orang lain.

\section{DAFTAR PUSTAKA}

Black, S. 2003. The Creative Classroom. American School Board Journal. September 2003, p 68-70

Budi Raharjo. 2011. Belajar Pemrograman WEB. Bandung: Modula

Hamdy taha. 2002. Operation Research. Bandung: Bina Rupa Aksara

Herawati Susilo. 2008. Penelitian Tindakan Kelas sebagai Sarana Pengembangan Keprofesionalan Guru dan Calon Guru. Malang: Bayu Media

Made Wena. 2009. Strategi Pembelajaran Inovatif Kontemporer: Suatu Tinjauan Konseptual Operasional. Jakarta: Bumi Aksara

Suharsimi Arikunto. 2006. Penelitian Tindakan Kelas. Jakarta: Bumi Aksara.

Suroso. 2007. Penelitian Tindakan Kelas. Yogyakarta: Pararaton

Widiyanto. 2008. Proses Belajar dan Pembelajaran. Jakarta: Kencana. 